\title{
The Art of Chinese Philosophy: Eight Classical Texts and How to Read Them. Paul R. Goldin
}

Princeton: Princeton University Press, 2020. Pp. xi+341

\section{Yi Chen ${ }^{1}$}

Received: 20 May 2021 / Revised: 14 June 2021 / Accepted: 25 June 2021 /

Published online: 1 September 2021

(C) The Author(s), under exclusive licence to Springer Nature Switzerland AG 2021

In a remarkable historical coincidence, the world's great philosophies and religions from the Yellow River to the Aegean sea - stem from the same period of time, about 700 to $200 \mathrm{BCE}$, when societies turned away from myth and towards the actually observed world, and when "Philosophers appeared for the first time" (Jaspers 1949, p. 19). Karl Jaspers named this the "Axial Age", and in China it covers the Spring and Autumn and the Warring States periods. Paul Goldin's 2020 introduction to classical Chinese philosophy presents eight major texts from that time, texts that we have come to regard as canonical for this era in which China's unity gained form, and which still speak to us today. The Analects, Mozi, Mencius, Laozi, Zhuangzi, Sunzi, Xunzi, and Han Feizi are brought to bear on three main questions: "What obligations do human beings have toward one another, and why? How do we construct an ideal government? What is a life well lived?" and the meta-question: "How do we answer such questions for ourselves, seeing that gods and spirits [...] have failed to do so?" (p. 1). Seeing this landscape laid out so broadly, we are in an excellent position to reflect on what, indeed, is the "art" of Chinese philosophy, and how we would teach it.

Confronted with such comprehension, I feel like one of Zhuangzi's characters, Master North-Gate, who appears in what is perhaps the Zhuangzi's philosophically deepest tale, and the most wondrously poetic, in which the Yellow Emperor (Huángdi ${ }^{1}$ 黄帝) plays music in the marshes around Lake Dòngtíng (洞庭), for an audience of one: his minister North-Gate Chéng (Běimén Chéng 北門成). Master North-Gate is profoundly moved: at first shaken (jù 眐), then weary (dài 急), then finally bewildered (huo 惑) - and that is exactly how the Yellow Emperor meant it to be (Zhuangzi,

\footnotetext{
${ }^{1}$ The reviewer uses pinyin with tone marks; romanization that appears in quoted text is kept as in the respective source.
}

Yi Chen

yi.chen.acad@gmail.com

1 Käte Hamburger Centre for Apocalyptic and Post-Apocalyptic Studies, Heidelberg University, Heidelberg, Germany 
“Heavenly Motions”, 《莊子·天運》 ${ }^{2}$ ). Shaken, weary, then bewildered - how is this so?

\section{Being Shaken}

The concert of the Yellow Emperor appears to be no music at all: it is the very experience of being, its profoundly unpredictable nature, incessant presence, and as incomprehensible as a thunderclap. Accordingly, at first Master North-Gate is shaken, even "terrified" as some translations have it: he stands in awe before its breadth and depth, he cannot escape its agitations, yet there is not one thing he could rely on. Indeed, the systems of Chinese philosophy can be like that. Their polyphonic voices have emerged over centuries, in the minds of the subtlest persuaders, the most authoritative thinkers, and the most charismatic scholars of their time, yet, although there is an unmistakable unity of thinking, "not a single thing one can depend on"3 (而一不可待 ibid.).

Goldin constructs a stable ground from two poles and two judges. On one hand, there is the "Philosophy of Heaven", the philosophies of the Analects, of Mozi, and Mencius, who conceive the innate - Heaven given - nature of human beings as a source of the responsibilities that build relationships and societies; its complement is the "Philosophy of the Way", the cosmological principles spelled out in Laozi, their illustration in the spirited tales in Zhuangzi, and the deep insights into Daoist resolution of dichotomies that the Sunzi casts into military strategy. This landscape of two poles is appraised implicitly and explicitly by "Two Titans at the End of an Age": Xunzi, whose scholarship has conventionally been grouped with the Confucians - though his "claim that xing is evil means that following the impulses of one's xing, without reflecting on them and moderating them, will lead one to evil acts." (p. 171) - and Han Feizi whose legalist doctrines formed the backbone of China's first empire, though his criticism of the Confucians (e.g. p. 210-211) or his outright Machiavellian reinterpretation of Daoist non-action (eg. p. 212) has ultimately not diminished the importance of either of the two.

This construction is an innovation that allows refreshing insights - re-discovering the Sunzi, which is not normally part of the canon is one of them - yet the emphasis on a distinction between tiān (天) and dào (道) has implications that we need to be aware of. When considering the unique contributions that Chinese philosophy has made, "relationality" would come to mind, and the "resolution of dichotomies" or "non-dualist thinking"; whether the concepts of tiān and dào are good metonymies, or workable alternatives is a question I will return to below. We also need to be aware that significant parts of Chinese philosophy are not included here - the "School of Names" (míngjiā 名家), ${ }^{4}$ for example is not independently given space - and the "classical" texts stem from a single period in time, and therefore neither Buddhist nor Neo-Confucian voices are included. Perhaps the most noticeable absence though is the Book of Changes 《易經》, one of the roots of Chinese philosophy. The reason would

\footnotetext{
${ }^{2}$ Where not otherwise indicated, Chinese text was retrieved from the ctext corpus (Sturgeon, 2019).

${ }^{3}$ Where not otherwise indicated, English translations are by the reviewer.

${ }^{4}$ Interested readers might refer to Mou 2018.
} 
be naturally that those do not fit Goldin's otherwise compelling paradigm, to give space to the text, and in particular, such text that shares comparable historical circumstances.

Thus "Heaven" and "Way" enter their dialogue, and Goldin does not fail to remind us that it would be naïve to take this literally. These are not conversations between individuals, but ideas and systems that emerged in recursive interactions, that were recorded by many hands, and edited into their final form often several generations later. Coincidentally, the proper way to deal with such intertwining would indeed be the same approach that Goldin presents as the unique and unifying mode of Chinese philosophical thinking: "non-deductive argumentation" - from "paradox, analogy and appeal to example" (p. 15) - which requires the reader's "connoisseurship" to appreciate and to develop a personal taste (p. 27), rather than knowledge. Indeed, although the etymology of Latin cognoscere (to know) might obscure this, the key to the relationship between the eight classics is a multi-dimensional effort, that allows the taste to linger, the thought to unfold, and the meaning to develop.

Goldin prefaces each text with the state of knowledge on the manuscripts' genesis, and expertly models the historical scholarship on which his interpretations are based. The implied conclusion is that the question of authorship and "original" text perhaps matters a bit less than we might think, and that the fixation on individual genius and authority may obscure the deeper philosophical questions. In that sense, one of the strengths of Goldin's book is the abundance of quoted text, made accessible in careful, trustworthy translations, and a lucid narrative on genesis, context and relationships, that is complemented with a layer of scholarly footnotes, which provide an excellent introduction to current discourse, but do not detract from the essence of a first encounter's essence: to read and to appreciate. A detailed analysis of the semantic evolution of qi (氣) in an Appendix of the book provides an illustrative example of etymological scholarship.

For an introductory course on "Chinese Philosophy", this book will make a sound choice, not only because of its unique comprehensiveness, and its modelling of scholarship, but especially for its emphasis on the original text, which distinguishes it from comparable works, such as Karyn Lai's An Introduction to Chinese Philosophy (2008). However, such authenticity comes at a cost: the text itself requires interpretation, and whether such interpretation is based on historical-philological, or on philosophical considerations is an issue that is tangible throughout.

For example, instead of grouping together the Confucian texts Analects, Mencius, and Xunzi, Goldin's "Philosophy of Heaven" places Mozi after the Analects. Indeed, the incompatible positions of Confucians and Mohists on relationship appear to have clashed in their time and Goldin uses the occasion to show how the Mozi's theodicy requires a universal moral standard that was not convincing to rulers and their subjects. But then, instead of addressing the question of whether and how the philosophy of the Mozi is meaningful for our times, Goldin focusses on the historical failure of Mohism: its lack of "a robust notion of self-cultivation", and that it "requires taking too much on faith" (p. 57). Yet the survival of the Mohists" ideas in the "School of Names", that the later Mohists contributed to, is missing (cf. Lai 2008, p. 123-130).

Another surprise is how far apart Goldin sees Laozi and Zhuangzi, especially in their political philosophy. Where we habitually speak of “Lăo Zhuāng” (老莊) to emphasize coherence, Goldin claims that Laozi promotes a concept of yú (愚), - which incidentally is the goal of Master North-Gate's education, but has an alternate sense of "stupid", or 
"foolish" - with disastrous political consequences, opening the gates for an authoritarianism that is based on deliberate ignorance: "If making the people 'think their food sweet, their vestments beautiful, their dwellings secure, and their customs delightful' calls to mind North Korea, where much of the citizenry lives within range of South Korean airwaves, but is too terrified to inquire further, one can only wonder whether Laozi has, directly or indirectly, inspired the regime" (p. 125). This is jarringly at odds with the "taste" of Laozi. Goldin's interpretation is based on excerpts such as Laozi 65 which opens: "Those who were adept at practicing the Way in the past did not enlighten the people, but made them ignorant. What makes the people difficult to govern is too much wisdom"5 (p. 124); I would translate instead: "The ancient masters of the dào did not use it to enlighten the people, but followed it to attain their simplicity. Leading the people is hard, if done with excessive cleverness". Indeed, the chapter continues quite clearly: "Therefore governing with cleverness is plundering the country, abstaining from cleverness is the country's fortune. Knowing the difference discloses the principle. Constantly employing this principle may be called a 'subtle virtue' (xuán dé 玄德). Such 'subtle virtue' is so deep, so far reaching, that it achieves the reversal of things; through that, the great fulfilment is gained." ${ }^{, 7}$ There is no trace of cynical oppression to be found here, on the contrary, the ancient sages - invariably a metaphor for enlightened governance - led collaboratively, embodying down-to-earth honesty, and doing nothing special to achieve everything important. That it is possible to come to such diametrically opposite understanding should remind us of the difficulty of the task.

\section{Becoming Weary}

The second level of achievement for Master North-Gate comes from his futile attempt to apply his preconceptions to the Yellow Emperor's music; that only made him weary: as the Yellow Emperor explains: "I stop where there is an end, and I flow where there is none. You want to conceive, but that cannot lead to understanding [...] Eyes know the bounds of visibility, strength conforms to intent. The self cannot achieve that. To fill emptiness with your own form, you would have to bend like a snake. You bend like a snake, that wearies you"8 (Zhuangzi, "Heavenly Motions"). This point is well taken: be cautious, you soon find yourself seeking your own ideas' reflection, rather than appreciating what is there.

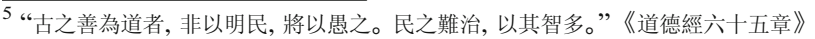

6 “故以智治國, 國之賊; 不以智治國, 國之福。知此兩者亦塴式。常知塴式, 是謂玄德。玄德深矣, 遠矣, 與物反矣, 然後 至大順。”《道德經六十五章》

${ }^{7}$ This much more "Daoist" understanding of the passage is well supported by scholarship. In his new reference translation of Laozi, where this chapter is extensively discussed, Guying Chen asserts: "The theme of this chapter has been generally mistaken by later generations who read it as Laozi advocating for obscurantist policies (愚民政策). However, the $y u$ 愚 [fool, foolishness, unsophisticated, ignorant, stupid] intended by Laozi, actually means genuineness and simplicity. He not only expects the people to be genuine and simple, but he requires the rulers in particular to pursue genuineness and simplicity for the sake of self-cultivation" (Chen 2020, p. 351-352).

8 “吾止之於有窮, 流之於無止。予欲虑之而不能知也......目知窮乎所欲見, 力屈乎所欲逐, 吾既不及已夫! 形充空虛, 乃至 委蛇。汝委蛇, 故急。”《莊子・天運》
} 
On one hand, Goldin's treatment avoids the conceptual divisions that have generally been applied. His Chinese philosophy is no longer segregated according to "isms": Confucianism, Daoism etc., nor by its leading figures; in fact, Goldin contests the legitimacy of the popular understanding of the “one hundred school disputes" (百家爭鳴) in the first place, and argues that the very notion of school - jia (家) - that emerged from the Warring States period does not capture the essence of the mind that solely belongs to the text itself (p. 2). Goldin's comments on the Analects are exemplary for how the meaning flows out from there, beyond the text. Prepared with his description of the meticulous and responsible work of the imperial librarians and Hàn 漢 dynasty editors such as Liú Xiàng (劉向), who played a crucial role in canonizing Confucian philosophy for the emperor, we know that the ancient "classics" are a complex of stewardship, placed in a context of imperial needs: legitimacy, governance and education. Through all these contingencies, Goldin helps us to distil a consistent philosophical idea from the text itself. In particular, he explains why Confucius himself did not leave written text, rather he preferred to teach "personally" (p. 35), and to adjust his teaching to the individual needs of each student. The Confucian red thread of his teaching is the concept shù 恕 (reciprocity), which Goldin explains from a deeper perspective of empathy, rather than merely following the more generally promoted, rather superficial understanding of shì as an instance of the Golden Rule (p. 38; p. 50). Of special significance for Confucius - as Goldin illustrates from a comment on the quintessentially Confucian concept of rén (仁) to his favourite student Yán Yuān (顏淵) - is not to establish and to follow a laundry list of moral and ethical dictates, and especially not to preach obedience to rules of behaviour and subservience to social norms, but to develop, confidently, an inner moral conscience that fundamentally rests on one's inner self (p. 42-43). This is indeed the Confucian taste: an uncompromisingly personal aesthetics that should not be separated from ethics, and Goldin time and again shows how this ideal of a proudly and confidently embodied propriety flows into the other "classics" and how they are in conversation with the Analects.

On the other hand, the concept of a tiān / dào distinction becomes a dominant paradigm for Goldin's analysis, even Laozi is discussed as a kind of response to the Confucians: "All the texts in part 1 use the word dao, but not nearly as frequently, and, crucially, without any cosmic connotations. In these earlier texts, dao usually means 'right conduct, right course of action,' but sometimes it refers to any habitual course of action, right or wrong. [...] We cannot be sure that Laozi was the very first text to use the word dao in its radically new sense, but the text is representative of intellectual trends that emerged around the fourth century $\mathrm{BC}$ and whose significance was grasped almost immediately" (p. 111). Here, a note of caution is in order: is it not precisely the Daoist commitment to non-duality that motivates Confucius to unify self and other into "relationship", expressed through the key concepts rén 仁 and $l \grave{l}$ 禮? Though perhaps expressed more explicitly in the Book of Rites than in the Analects, the Confucians' premise is always that propriety follows from the proper order, and that is an order according 
to the nature of things; ${ }^{9}$ and more, the very principles that Confucius applied to define the rules of propriety ( $l i$ 禮), which had been lost to history, were taken from his reading of Daoist Yin-Yang cosmology. ${ }^{10}$ This would hardly be surprising, after all, the unity of tiān and dào, and a cosmological understanding of the latter is a prominent theme of the Book of Changes which precedes Confucius by hundreds of years. ${ }^{11}$

\section{Achieving Bewilderment}

In Zhuangzi's tale, the Yellow Emperor's final gift to Master North-Gate is "bewilderment", and for a Daoist, achieving a non-conceptual state is the highest form of understanding. This is the gate that one must pass through towards yu 思 - the "foolishness" we have discussed above - to finally achieve the dào. ${ }^{12}$ Only once conceptualization has been overcome, and things begin to appear according to their true nature, only then can the apparent opposites be resolved. Of note: this Aufhebung is not a resolution in Hegel's sense, but actually achieves the paradox. Realizing the "art" of Chinese philosophy would be such an achievement. Can I - despite the concepts and categories I was trained in - discern a unity of thought, a sequence of relationships, or even a system of philosophy from the eight texts? This is not just a question for myself: exactly because it is easy to imagine how an entire generation of sinologists may have their first encounter with Chinese philosophy on these pages, the normative implications of Goldin's work become an important issue. Let us engage with the subtleties of the philosophy we encounter here in three points.

\subsection{Quán 權: Grounding the Good}

In his discussion of Mencius, Goldin quotes a famous passage in which the quintessential Confucian concept of ritual-propriety $(l \check{l})$ is deemed to demand that "when males and females give and take, they are not to touch each other" (男女授受不親) (p. 79-80). In his translation, Goldin follows the colloquial Chinese understanding, and reflects the setting for a debate between Mencius and the royal advisor, Chúnyú Kūn (淳于髨), who challenged Mencius: if his sister-in-law were to be drowning, should he reach out his hand to save her? Mencius replied that, while the rule itself is $l i$, i.e. proper, circumstances may allow actions to be dictated by quán (權), which Goldin

\footnotetext{
${ }^{9}$ Expressed for example, when Confucius reflects on a former state of societal harmony as the proceeding of the "Great Dào" (大道) in the chapter "Lú Yùn" of the Book of Rites《禮記・禮運》.

10 "From the meaning of Kün Qián, and the almanac of Xià, I deduced [the Lĭ 裋]" (Book of Rites, Lì Yùn) (坤 乾之義, 夏時之等, 吾以是觀之。《禮記・禮運》). Kün Qián 坤乾, the Earth and Heaven trigrams are texts on yin 陰 yáng 陽 cosmology that were considered ancient even in Confucius' times.

${ }^{11}$ For example: "How the tracks of tiān are due to the supreme process of the dào" Book of Changes, "Dà Xù" ( 「何天之量, 道大行也。」《易經・大畜象傳》).

${ }^{12}$ In the words of the Yellow Emperor: "As for music, it starts from being shaken, being shaken turns to awe; I add more to cause weariness; being weary you flee; it culminates in bewilderment, bewildered, therefore stupefied; stupefied, therefore dào, as the dào can carry, so it accompanies as well" Zhuangzi, "Heavenly Motions” (樂也者, 始於懼, 懼故崇; 吾又次之以急, 急故遁; 卒之於惑, 惑故愚; 思故道, 道可載而與之俱也。《莊子・天 運》).
} 
translates as "disregarding an otherwise norm in exigent circumstances" (p. 80). This is a profoundly important passage, which deserves to be carefully interpreted for itself and its wide-ranging implications. The issue here is the frequently propagated misunderstanding of qīn (親) as "touch" and quán as "expediency" - i.e. both are superficial behaviors; going with the Confucian "taste" however, we should understand that qin is literally "intimacy", an attitude, and quán also means "authority". In this reading, Mencius' actual intent is to remind Chúnyú Kūn that a norm that rests on inner principles entails one's personal authority to act in various ways, without weakening the principle at all.

Seen in this way, it is curious that Mencius takes Chúnyú Kūn's bait in the first place. After all, there is no expediency involved. The superficial understanding of this passage that is prevalent even in China in fact amounts to a betrayal of the Confucian position that the good must be pursued authentically, mere behavior is not sufficient. Indeed, the subtle, popular corruption of Confucian ethics in Chinese history by focusing on behavior, not authenticity - exemplified in understanding Mencius' quán as expediency - is quite well understood by the literati, so for example by Cáo Xuěqín (曹雪芹 1715-1763), who in the greatest Chinese novel The Dream of the Red Chamber 《紅樓夢》takes quán as synonymous for corruption, by naming Dài Quán 戴權, an imperial eunuch, who sells official posts for outrageous amounts of silver. This deeper meaning of Mencius' quán is the key to unlock the philosophy; the allegorical relation of this passage to Mencius' political engagement that becomes the focus of Goldin's interpretation has comparatively little to contribute.

\subsection{Dé 德: Embracing Paradox}

As mentioned above, a quintessential idea of Chinese philosophy is non-oppositional duality. Goldin quotes, twice, Laozi's doctrine: "The highest virtue is not virtuous; therefore, it has virtue" (上德不德, 是以有德 Laozi 38, p. 16-17; and again, p. 111). Yet he considers that the apparent paradox can be explained away:

For "The highest virtue is not virtuous" to have any intelligible meaning, the keyword $d e$ 德 (virtue, inner power) must be taken in two different ways. The first de, called shangde 上德, or the highest virtue, refers to de that is real and potent because it derives from the dao 道 itself, whereas the second de, merely de, refers to the great sham that human society, in its self-induced ignorance, wrongly identifies as $d e$. Thus, the highest virtue has real virtue precisely because it is not the false virtue that everyone has been trained to venerate. (p. 17)

Goldin is by no means alone in asserting that the real meaning here can be inferred once the paradox is removed and the proposition can acquire a definite truth-value. Yet this semantic trick in fact trivializes the Daoist position, which rather expresses a true dialetheia - a proposition that is simultaneously true and false, and which is not to be understood "as invoking some sort of mysticism, but as affirming the nature of reality" (Priest, 2018). There are several approaches in the analytic tradition to formalize this understanding, referred to as "paraconsistent logic" (ibid.), yet, a good, accessible interpretation of the Daoist position does not actually require the resolution of the paradox at all: at least for a first order approach it suffices to state that the paradox is 
intentional, and what is being spoken about contains both the statement and its negation, and must not be decomposed. Here Chinese philosophy is at its most characteristically different from Western traditions and given how pervasive this aspect of Daoist philosophy is, and how influential it has become, e.g. when it fused with Mahayana Buddhism to chán (禪) and Japanese Zen, this becomes a non-trivial issue in the quoted paragraph, and elsewhere.

\section{3 “Heaven" (Tiān 天) and the "Way" (Dào 道)}

As stated above, the distinction between tiān and dào is part of the basic structure of the book. Yet, at the beginning of the Doctrine of the Mean (Zhōngyōng 《中庸》), it is said, "That which the Mandate of Heaven (tiānming 天命) brings forth is called nature (xing 性); that which leads nature is called dào (道, the Way), [...]” (天命之謂性, 率性之 謂道......). Here, understanding the connection between tiān 天 and dào 道 via the nature of things, xìng 性, pivots on the verb shuài 率, to "follow", which indicates an inherence, not a causal sequence. In this case, the mandate of tiān 天 is the normative aspect that is conjugated with the inherent quality of the dào. Unless the point is precisely to speak of the distinction between something being good, and it being realized that it is good, I would maintain that it is convergence, rather than distinction that characterizes the relationship of tiān and dào. One hopes that this point can be well appreciated by readers of this book.

I have picked up these subtle points - and others could be made - to define a challenge that we will need to live up to, as educators and as scholars: Paul Goldin's book gives us the text, makes it accessible and leads us through a first interpretation, and it does this very well. Like Master North-Gate, we ought to be shaken considering the breadth of the ideas that are covered, and the scope of the philosophy that appears behind it. Though like Master North-Gate, we might be wearied were we to follow Goldin's guidance to view the relationships from a higher vantage point, and to discover implications that are easily overlooked when considering the texts individually, if we were to do so from our preconceptions. Yet, like Master North-Gate we cannot stop there, the deeper beauty, the real "Art of Chinese Philosophy" is yet to come. As with any work of art, the key is to learn - and teach - to see for ourselves. Goldin's book is well placed to get us started.

Code Availability Not applicable.

Data Availability Not applicable.

\section{Declarations}

Conflicts of Interest/Competing Interests The reviewer has no financial or proprietary interests in any material discussed in this article.

\section{References}

Chen, G. (2020). The annotated critical Laozi: With contemporary explication and traditional commentary. Brill

Jaspers, K. (1949). Vom Ursprung und Ziel der Geschichte (The origin and goal of history). Piper 
Lai, K. L. (2008). An introduction to Chinese philosophy. Cambridge University Press

Mou, B. (Ed.). (2018). Philosophy of language, Chinese language, Chinese philosophy: Constructive engagement. Brill

Priest, G., Berto, F., \& Weber, Z. (2018). Dialetheism. In E. N. Zalta (Ed.), The Stanford encyclopaedia of philosophy. https://plato.stanford.edu/archives/fall2018/entries/dialetheism/

Sturgeon, D. (2019). Chinese text project: A dynamic digital library of premodern Chinese. Digital Scholarship in the Humanities, 36, i101-i112. https://doi.org/10.1093/llc/fqz046 http://ctext.org 